\title{
Procoagulant Phosphatidylserine-Exposing Platelets in vitro and in vivo
}

\author{
Emily C. Reddy ${ }^{1+}$ and Margaret L. Rand ${ }^{2,3 *+}$ \\ ${ }^{1}$ Developmental and Stem Cell Biology, Research Institute, The Hospital for Sick Children, Toronto, ON, Canada, ${ }^{2}$ Division of \\ Haematology/Oncology, Translational Medicine, Research Institute, The Hospital for Sick Children, Toronto, ON, Canada, \\ ${ }^{3}$ Departments of Laboratory Medicine \& Pathobiology, Biochemistry, and Paediatrics, University of Toronto, Toronto, ON, \\ Canada
}

OPEN ACCESS

Edited by:

Marie Lordkipanidzé,

Université de Montréal, Canada

Reviewed by:

Matthew Harper,

University of Cambridge,

United Kingdom

Mikhail Panteleev,

Lomonosov Moscow State

University, Russia

Marina Camera

University of Milan, Italy

${ }^{*}$ Correspondence:

Margaret L. Rand

margaret.rand@sickkids.ca

†These authors have contributed equally to this work

Specialty section:

This article was submitted to Atherosclerosis and Vascular

Medicine,

a section of the journal

Frontiers in Cardiovascular Medicine

Received: 15 October 2019

Accepted: 30 January 2020

Published: 03 March 2020

Citation:

Reddy EC and Rand ML (2020)

Procoagulant

Phosphatidylserine-Exposing Platelets

in vitro and in vivo.

Front. Cardiovasc. Med. 7:15.

doi: 10.3389/fcvm.2020.00015
The physiological heterogeneity of platelets leads to diverse responses and the formation of discrete subpopulations upon platelet stimulation. Procoagulant platelets are an example of such subpopulations, a key characteristic of which is exposure either of the anionic aminophospholipid phosphatidylserine (PS) or of tissue factor on the activated platelet surface. This review focuses on the former, in which PS exposure on a subpopulation of platelets facilitates assembly of the intrinsic tenase and prothrombinase complexes, thereby accelerating thrombin generation on the activated platelet surface, contributing importantly to the hemostatic process. Mechanisms involved in platelet PS exposure, and accompanying events, induced by physiologically relevant agonists are considered then contrasted with PS exposure resulting from intrinsic pathway-mediated apoptosis in platelets. Pathologies of PS exposure, both inherited and acquired, are described. A consideration of platelet PS exposure as an antithrombotic target concludes the review.

Keywords: platelets, procoagulant, phosphatidylserine (PS) exposure, platelet activation, platelet apoptosis, hemostasis, thrombosis

\section{INTRODUCTION}

Blood vessel wall injury sets into play processes that lead to the formation of a hemostatic plug that stops the bleeding from the injury site. In primary hemostasis, platelets adhere to exposed subendothelium, resulting in their activation and aggregation, forming a platelet plug. Secondary hemostasis is initiated by tissue factor exposure at the site of vessel wall damage, resulting in formation, via the coagulation pathway, of covalently cross-linked fibrin that binds to, and stabilizes, the platelet plug (1).

It has long been recognized that activated platelets contribute in a major way to fibrin formation; this is well-exemplified in the cell-based model of coagulation (2). This procoagulant property of platelets, earlier termed platelet factor 3 availability ( $\mathrm{PF} 3 \mathrm{a}$ ) and assayed by measuring the ability of platelets to promote thrombin and fibrin formation (3), results from exposure of the anionic aminophospholipid phosphatidylserine (PS) on the surface of activated platelets (4). PS, translocated from the internal to the external platelet membrane leaflet, facilitates the assembly of the intrinsic tenase complex [factor (F)VIIIa; FIXa; FX] and prothrombinase complex (FVa; FXa; prothrombin), contributing to the burst of thrombin generation in the propagation phase of coagulation. Specifically, the negatively charged $\gamma$-carboxyglutamate (Gla) residues at the $\mathrm{NH}_{2}$ termini of the vitamin K-dependent factors, $\operatorname{FIX}(\mathrm{a}), \mathrm{FX}(\mathrm{a})$, and prothrombin, interact with negatively charged PS via $\mathrm{Ca}^{2+}$. FVIII binds to PS via its $\mathrm{C} 2$ domain and FVa via its $\mathrm{C} 1$ and $\mathrm{C} 2$ 
domains $(5,6)$. Tenase and prothrombinase activities are enhanced by PS-containing membranes by up to three orders of magnitude (7-9). Phosphatidylethanolamine (PE), that also becomes exposed on the surface of activated platelets, can contribute to the enhanced thrombin formation $(7,10)$; the fatty acid chain length of PE, but not PS, regulates the ability to support coagulation, with platelet-specific PEs demonstrating optimum activity (11). Oxidized PE, specifically 12-hydroxyeicosatetraenoic acid (HETE)-PE, formed by activated platelets, is even more potent than native $\mathrm{PE}$ in enhancing thrombin generation (12).

It is recognized that tissue factor-expressing platelets also comprise a subpopulation of procoagulant platelets. However, a discussion of this type of procoagulant platelet is beyond the scope of this mini-review, and the reader is referred to several recent, relevant publications on the topic (13-18).

\section{Procoagulant \\ Phosphatidylserine-Exposing Platelet Subpopulations and Nomenclature}

A unique feature of procoagulant platelet formation is that only a subpopulation of activated platelets exposes PS. This was recognized over 25 years ago by flow cytometry (19) using fluorescently labeled annexin A5 that binds PS with high affinity in a $\mathrm{Ca}^{2+}$-dependent manner. Fluorescently labeled lactadherin that does not require $\mathrm{Ca}^{2+}$ is also used to detect PSexposing platelets [e.g., Dasgupta et al. (20)]. Flow cytometric and microscopy studies have shown colocalization of FVIII(a), FIX(a), FX(a), FV(a), and prothrombin with PS-exposing platelets, confirming that these platelets serve as assembly sites for the intrinsic tenase and prothrombinase complexes (21-25).

Procoagulant platelet subpopulations have been referred to by a myriad of names in the literature; however, it is recognized that these platelets share the key characteristic of PS exposure. An early description of a subpopulation of PSexposing platelets was as COAT (COllagen And Thrombin)-FV platelets formed in response to dual agonist activation. These platelets were characterized by high levels of FV on their surface, in addition to PS $(22,26)$. COAT-FV was later abbreviated to COAT when it was demonstrated that these platelets are also coated with fibrinogen, fibronectin, von Willebrand factor (VWF), and thrombospondin, among many other $\alpha$-granule proteins, on their surface (27). Subsequently, this subpopulation has been termed coated platelets, denoting the coating of the platelets with procoagulant proteins, including fibrin (28-30). The distinct morphology of procoagulant platelets has led to the terminology of blebbing, balloon(ing), or balloon-like platelets (31-35). Procoagulant platelets have also been referred to as SCIP (sustained calcium-induced platelet morphology) platelets (36), necrotic/4-[N-(S-glutathionylacetyl)amino]phenylarsonous acid (GSAO)-binding platelets (37-39), superactivated platelets (40), capped platelets $(21,41)$, and zombie platelets (42). Agbani and Poole (43) recently proposed "procoagulant platelets" as the unifying term for this activated platelet subpopulation.

In this brief review, we focus on mechanisms involved in PS exposure induced by platelet activation to form a subpopulation of procoagulant platelets, then contrasting it with PS exposure resulting from platelet apoptosis. Pathologies of PS exposure, inherited and acquired, are described. We conclude with a consideration of platelet PS exposure as an antithrombotic target.

\section{PLATELET MEMBRANE PHOSPHOLIPID ASYMMETRY: MAINTENANCE AND COLLAPSE}

\section{Flippase [(Aminophospholipid) Translocase]}

Similar to other biological membranes, resting platelets possess an asymmetrical phospholipid plasma membrane bilayer (4), with the minor phospholipid PS sequestered to the inner cytoplasmic leaflet. This PS asymmetry is created by a flippase/(amino)phospholipid translocase enzyme, a member of the Type IV subfamily of P-type ATPases (P4-ATPases) (9, 44 ), that rapidly and specifically shuttles PS from the outer to the inner membrane leaflet against the concentration gradient, in an ATP-dependent fashion (45). Its activity is abrogated when cytoplasmic $\mathrm{Ca}^{2+}\left(\mathrm{Ca}^{2+}{ }_{\text {cyt }}\right)$ increases to low micromolar levels (46).

\section{Scramblase and TMEM16F}

Scramblase is a $\mathrm{Ca}^{2+}$-dependent, ATP-independent enzyme that regulates the rapid, non-specific bidirectional movement, i.e., "scrambling," of phospholipids between membrane leaflets, resulting in a loss of normal membrane phospholipid bilayer asymmetry. Although scramblase activity has long been described in platelets (4), the protein involved in $\mathrm{Ca}^{2+}$. dependent PS exposure was only identified a decade ago as TMEM16F (anoctamin 6) (47-49). It is a member of the multiple transmembrane (TMEM)16 (anoctamin) domain family of proteins, of which the first-described member, TMEM16A, is a $\mathrm{Ca}^{2+}$-activated $\mathrm{Cl}^{-}$channel. TMEM16F has been described to be a $\mathrm{Ca}^{2+}$-dependent $\mathrm{Cl}^{-}$channel, a $\mathrm{Ca}^{2+}{ }_{\text {-regulated non-selective }}$ cation channel permeable for $\mathrm{Ca}^{2+}$, or a $\mathrm{Ca}^{2+}$-dependent phospholipid scramblase (49). Evidence is accumulating that TMEM16F is indeed itself a scramblase [e.g., Watanabe et al. (50); Le et al. (51)].

\section{PLATELET PHOSPHATIDYLSERINE EXPOSURE}

Several different pathways result in procoagulant platelet formation. In one, PS exposure occurs rapidly via platelet activation by strong agonists. A second is the intrinsic apoptosis pathway via which PS exposure occurs more slowly $(9,37,52$, 53). These pathways are considered in turn below, and key characteristics are summarized in Table $\mathbf{1}$. In a recently described third pathway that is distinct from the aforementioned canonical pathways, binding of oxidized low-density lipoprotein to platelet membrane glycoprotein (GP)IV (CD36) and signaling through extracellular signal-regulated protein kinase (ERK)5 mitogenactivated protein (MAP) kinase leads to PS exposure. This pathway may be relevant in thrombotic events that occur in dyslipidemia (54). 
TABLE 1 | Summary of key characteristics of platelet agonist- and apoptosis-induced PS exposure (Agonist-Induced Phosphatidylserine Exposure and Apoptosis-Induced Phosphatidylserine Exposure).

\begin{tabular}{|c|c|c|}
\hline & $\begin{array}{l}\text { Agonist-induced platelet PS exposure } \\
\text { (fast response) }\end{array}$ & $\begin{array}{l}\text { Apoptosis-induced platelet PS exposure } \\
\text { (slow response) }\end{array}$ \\
\hline Trigger & $\begin{array}{l}\text { Physiologically relevant: engagement of both GPVI } \\
\text { (collagen/convulxin/CRP) and PAR1/PAR4 (thrombin) } \\
\text { receptors } \\
\text { Non-physiological: } \mathrm{Ca}^{2+} \text { ionophores A23187, ionomycin }\end{array}$ & $\begin{array}{l}\text { Inhibition of pro-survival } \mathrm{Bcl}-\mathrm{xL} \text {, resulting in activation of } \\
\text { proapoptotic Bak and Bax } \\
\text { Non-physiological: ABT-737 }\end{array}$ \\
\hline Cytoplasmic $\mathrm{Ca}^{2+}\left(\mathrm{Ca}^{2+}{ }_{\text {cyt }}\right)$ concentrations & Sustained, elevated $\mathrm{Ca}^{2+}$ cyt levels required & Not dependent on sustained, elevated $\mathrm{Ca}^{2+}{ }_{\text {cyt }}$ levels \\
\hline Intracellular protease activation & $\begin{array}{l}\text { - Calpain activated } \\
\text { - Caspase activation occurs, but PS exposure is not } \\
\text { dependent on it }\end{array}$ & - Dependent on caspase activation \\
\hline TMEM16F & Required & Not essential \\
\hline Morphology & $\begin{array}{l}\text { - Rounded, blebbing platelets essentially empty of } \\
\text { cytoplasmic contents } \\
\text { - EVs are shed }\end{array}$ & $\begin{array}{l}\text { - Rounded, blebbing platelets with cytoplasmic contents } \\
\text { remaining } \\
\text { - EVs are shed }\end{array}$ \\
\hline
\end{tabular}

$\mathrm{Ca}^{2+}{ }_{\text {cyt }}$, cytoplasmic $\mathrm{Ca}^{2+}$; CRP, collagen-related peptide; EV, extracellular vesicle; GP, glycoprotein; IMM, inner mitochondrial membrane; MOMP, mitochondrial outer membrane permeabilization; MPTP, mitochondrial permeability transition pore; PAR, protease-activated receptor; PS, phosphatidylserine; $\Delta \Psi_{m}$, inner mitochondrial membrane potential.

\section{Agonist-Induced Phosphatidylserine Exposure}

Agonist-stimulated platelet surface PS exposure is a rapid process, occurring in seconds to minutes, and is accompanied by other apoptotic-like events, including mitochondrial membrane permeabilization and depolarization, and plasma membrane blebbing, with extracellular vesicle (EV) formation. The proportion of PS-exposing platelets formed depends on the agonist(s) used for platelet stimulation, with the most potent in vitro, physiologically relevant stimulus being the combination of collagen/convulxin/collagen-related peptide (CRP) plus thrombin $(\mathrm{C}+\mathrm{T})$ The former binds to GPVI, and the latter cleaves protease-activated receptor (PAR)1 and PAR4 (23), synergizing to set into motion the signaling pathways that result in the sustained, supramaximal levels of $\mathrm{Ca}^{2+}$ cyt (55) (see below) that are required for PS exposure on a substantial proportion of platelets. Anywhere from 20 to $40 \%$ of C+T-stimulated platelets become PS-exposing, with a wide variation between donors; singly, these agonists are not as potent, with a smaller proportion of PS-exposing platelets being formed (56). ADP or thromboxane $\mathrm{A}_{2}\left(\mathrm{TxA}_{2}\right)$ (using the stable mimetic U46619) does not play a major role $(23,33)$, while shear forces are effective $(57,58)$. The non-physiological, non-receptor-mediated ionophores A23187, and ionomycin, that directly increase $\mathrm{Ca}^{2+}{ }_{\text {cyt }}$, are the most potent stimulators of PS exposure, with typically $>90 \%$ of platelets taking on the procoagulant phenotype $(19,56)$.

Platelet stimulation by collagen (or convulxin/CRP) or thrombin [or the PAR-specific thrombin receptor activating peptides (TRAPs)] alone activates phospholipase (PL)C $\gamma$ (via GPVI) and PLC $\beta$ (via PAR1/4), resulting in a rise in $\mathrm{Ca}^{2+}$ cyt to the micromolar range (23). Cleavage of membrane phosphatidylinositol-4,5-bisphosphate by PLC forms inositol trisphosphate $\left(\mathrm{IP}_{3}\right)$ and diacylglycerol (DAG); the former induces the release of $\mathrm{Ca}^{2+}$ from internal stores, the dense tubular system (DTS), via $\mathrm{IP}_{3}$ receptors. Depletion of internal $\mathrm{Ca}^{2+}$ stores allows store-operated $\mathrm{Ca}^{2+}$ entry (SOCE) from the platelet exterior: briefly, stromal interaction molecule 1 (STIM1) in the DTS membrane undergoes a conformational change, allowing activation of Orail, the major $\mathrm{Ca}^{2+}$ releaseactivated $\mathrm{Ca}^{2+}$ channel in the platelet plasma membrane (23). DAG, together with $\mathrm{Ca}^{2+}$, activates protein kinase $\mathrm{C}(\mathrm{PKC}) \alpha$ that enhances $\mathrm{Na}^{+} / \mathrm{Ca}^{2+}$ exchange during $\operatorname{SOCE}(59,60)$. Sustained increases in $\mathrm{Ca}^{2+}{ }_{\text {cyt }}$ via release from internal stores, SOCE, and release of mitochondrial $\mathrm{Ca}^{2+}$ upon mitochondrial permeability transition pore (MPTP) formation (see below) in a small proportion of platelets activate scramblase. It is the dual stimulation of GPVI and PAR1/4 by $\mathrm{C}+\mathrm{T}$ that leads to the sustained, elevated levels of $\mathrm{Ca}^{2+}$ cyt necessary for PS exposure in a substantial proportion of platelets; the combination of $\mathrm{C}+\mathrm{T}$ activates store-independent, receptor-operated $\mathrm{Ca}^{2+}$ entry (ROCE). This involves non-selective cation transient receptor potential C (TRPC) channels, TRPC3 and TRPC6, that allow $\mathrm{Na}^{+}$entry. Coupling to reverse-mode $\mathrm{Na}^{+} / \mathrm{Ca}^{2+}$ exchange then leads to the sustained elevated $\mathrm{Ca}^{2+}{ }_{\text {cyt }}$ that activates scramblase (61).

$\mathrm{Ca}^{2+}{ }_{\text {cyt }}$ increases activation of the $\mathrm{Ca}^{2+}$-dependent cysteine protease calpain that has a number of substrates in platelets, including cytoskeletal components, signaling molecules, and 
the $\beta 3$ integrin subunit, thereby regulating many platelet responses, including spreading, secretion, aggregation, and EV formation $(36,62-64)$. In platelets stimulated to expose PS, calpain-2-mediated proteolysis of $\alpha \mathrm{IIb} \beta 3$-associated proteins and $\beta 3$ results in inactivation of $\alpha \operatorname{IIb} \beta 3$, the integrin necessary for platelet aggregation (65); thus, procoagulant platelets are unable to participate in aggregation. To that end, both in flow chambers coated with collagen and in mouse models of arterial thrombosis, two distinct microdomains of platelets are visualized in thrombi: 1) aggregated, non-PS-exposing platelets with extended pseudopods and activated $\alpha \operatorname{IIb} \beta 3$; surrounded by 2) PS-exposing platelets that have elevated $\mathrm{Ca}^{2+}$ cyt, inactivated $\alpha \mathrm{IIb} \beta 3$, a rounded morphology, and are shedding EVs (see below) $(32,36)$. Further, in these ex vivo and in vivo systems, PS-exposing platelets are observed to translocate to the surface of thrombi where they accelerate fibrin formation (66).

Mitochondrial integrity loss is an apoptosis hallmark that precedes agonist-induced PS exposure, with involvement of the inner mitochondrial membrane (IMM) Formation of the cyclophilin D-regulated MPTP, a non-selective multiprotein pore that spans the IMM, is a key step $(67,68)$, as PS exposure is reduced in convulxin+thrombin-stimulated cyclophilin Ddeficient platelets or platelets treated with cyclosporin A, an MPTP inhibitor (69-71). Reactive oxygen species, e.g., hydrogen peroxide $\left(\mathrm{H}_{2} \mathrm{O}_{2}\right)$, that can trigger MPTP formation, synergize with thrombin to expose platelet PS, indicating a role for oxidative stress in procoagulant platelet formation (69). Sustained MPTP formation leads to disruption of the IMM potential $\left(\Delta \Psi_{\mathrm{m}}\right)(72,73)$, and $\Delta \Psi_{\mathrm{m}}$ depolarization is associated with PS exposure both in agonist-stimulated platelets in vitro and platelets aging in vivo $(69,71,74-77)$.

In convulxin +thrombin-stimulated platelets, PS exposure is entirely dependent on $\Delta \Psi_{\mathrm{m}}$ loss and TMEM16F. However, there is evidence of a second minor pathway of PS exposure that occurs with collagen+thrombin stimulation that is independent of these $(76,78)$. This pathway may also be involved in the mitochondrial depolarization-independent PS exposure observed in A23187stimulated platelets in the presence of cyclosporin A (79). Heterogeneity within the PS-exposing platelet subpopulation has also been reported by Topalov et al. (80): one subset with high $\mathrm{Ca}^{2+}{ }_{\text {cyt }}, \Delta \Psi_{\mathrm{m}}$ loss, and inactive $\alpha \operatorname{IIb} \beta 3$; and another with low $\mathrm{Ca}^{2+}{ }_{\text {cyt }}$, intact $\Delta \Psi_{\mathrm{m}}$, and active $\alpha \mathrm{IIb} \beta 3$. Subsequently, this latter subset was described to be the result of the interaction between a procoagulant platelet and an aggregatory (non-PS-exposing) platelet (81).

Although caspase activation occurs upon mitochondrial depolarization and has been used as a marker in studies of agonist-induced platelet PS exposure, e.g., caspase-3 (75, 79), the agonist-induced pathway of procoagulant platelet formation appears to be independent of caspase activation $(52,82)$.

Near-complete shedding of GPIb $\alpha$ and GPVI mediated by ADAM17 and 10, respectively, is accompanied by PS exposure and modulates platelet function from less adhesive to more procoagulant (83).

In becoming procoagulant, platelets undergo remarkable morphological changes. Platelets adherent to collagen/CRP, but not fibrinogen, spread and transform into blebbing, rounded, balloon-like structures $(31,34)$. These collagen-adherent balloon platelets are PS exposing, as determined by annexin A5 binding $(32,33)$. Similarly, platelets stimulated in suspension by $\mathrm{C}+\mathrm{T}$ or A23187 form a distinct PS-exposing platelet subpopulation with a spherical, balloon-like morphology, almost devoid of granules and normal internal architecture (Figure 1) $(35,84)$. This ballooning has been attributed to activation of $\mathrm{Ca}^{2+}$ activated $\mathrm{Cl}^{-}$channels, resulting in initial salt entry into platelets, which is then followed by the influx of water (33). There is increased permeability of plasma membrane of the PS-exposing platelets to low-molecular-weight molecules $(33,71)$.

The unique surface protein coating of procoagulant platelets (Introduction) has been observed primarily localized to a small, convex structure, or cap, rather than distributed uniformly on the PS-exposing platelet surface; $85 \%$ of PS-exposing platelets possess caps, with one per platelet $(21,41)$. It was subsequently demonstrated that procoagulant activity is located in the cap, or remnant platelet body, early in balloon-platelet development, then becomes predominant in the balloon-like structure at later time points (85). Recently, it was observed that more than $90 \%$ of PS-exposing platelets possess one or multiple associated EVs that exhibit heterogeneity in platelet membrane glycoproteins and activation markers different from platelet-derived EVs free in suspension (see below) (Figure 1) (35).

PS exposure is accompanied by the release of membranebound EVs (previously referred to as microparticles or microvesicles) from the platelet plasma membrane (86); indeed, Scott syndrome platelets, that are deficient in PS exposure upon activation (Pathologies of Phosphatidylserine Exposure), are also deficient in EV formation $(87,88)$. EV surface membranes are heterogeneous in their expression of platelet membrane glycoproteins, e.g., $\alpha \operatorname{IIb} \beta 3$ and GPIb-IX-V, and activation markers, e.g., CD62P (P-selectin), CD63, and activated $\alpha \operatorname{IIb} \beta 3$ $(35,89,90)$, and only about half expose PS (86). Platelet-derived EVs support hemostasis and also play a role in platelet-cell communications, delivering bioactive molecules, e.g., cytokines, eicosanoids, RNA species, to target cells [e.g., Boilard et al. (91)]. Elevated circulating EV levels have been reported in thrombotic conditions, immune-mediated conditions, and malignancy and inflammatory conditions, but whether they are "active contributors" or "passive indicators" of these conditions is not known (86). EVs are cleared rapidly (92), implying that they must be produced continuously for circulating levels to be detected.

Once procoagulant platelet formation has been stimulated in vitro, PS exposure is not readily reversed; this is likely due, at least in part, to inhibition of translocase activity $(56,76,93)$, preventing the flipping of PS to the internal membrane leaflet. Even in vivo, PS exposure persists on activated platelets, as demonstrated by a study in which rabbit platelets stimulated to expose PS in vitro continued to circulate when injected into recipient rabbits (94). Although PS is a clearance signal of apoptotic cells by macrophages (see below), there are examples of cells that express PS constitutively and are viable $(95,96)$. 


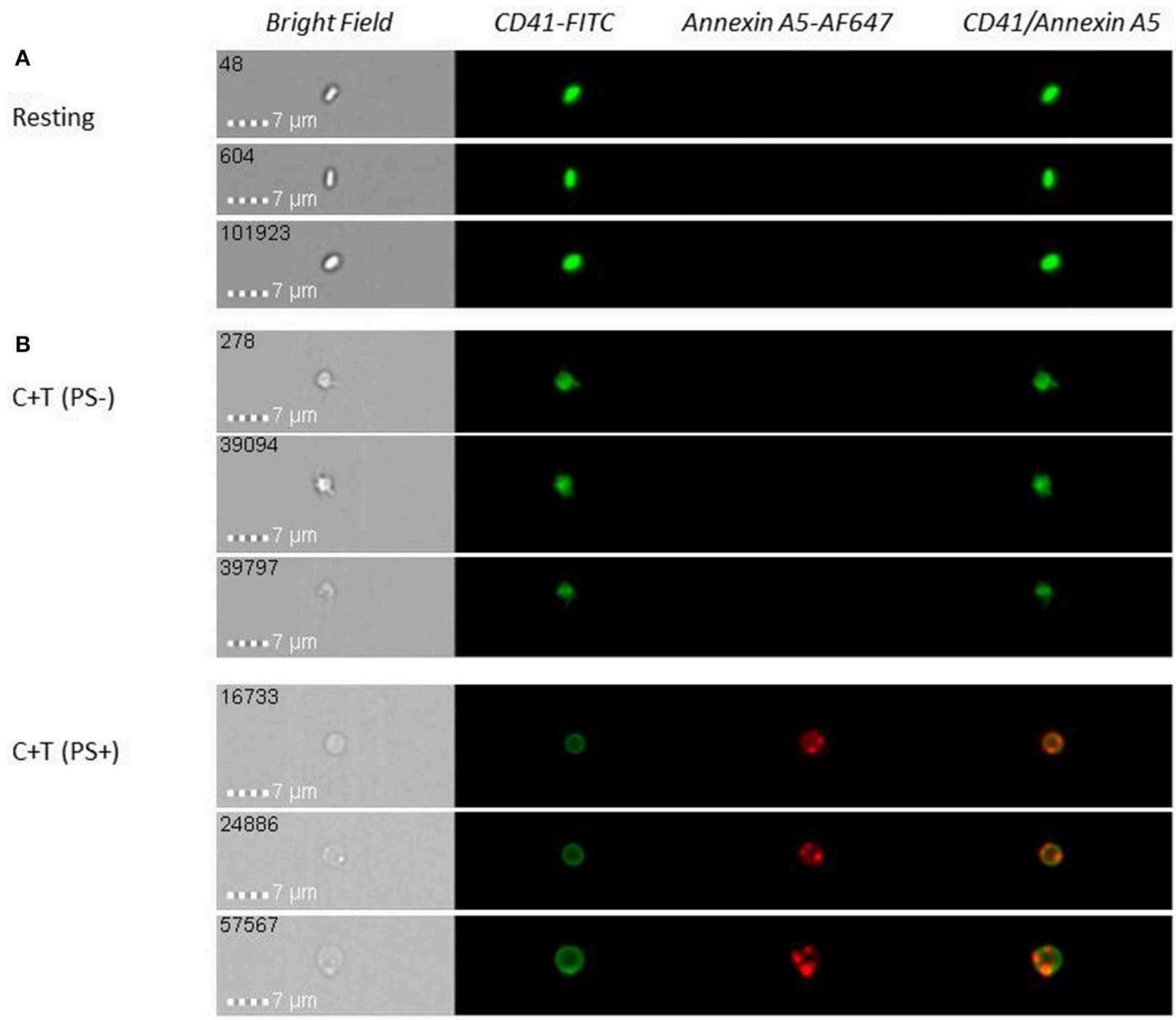

FIGURE 1 | Upon platelet activation with collagen $(10 \mu \mathrm{g} / \mathrm{ml})$ + thrombin $(1 \mathrm{U} / \mathrm{ml})(\mathrm{C}+\mathrm{T})$, a subpopulation of phosphatidylserine (PS)-exposing platelets with a round, balloon-like morphology and one or more associated extracellular vesicles (EVs) is formed. Resting (unstimulated) (A) or stimulated (B) washed platelets were labeled with anti-CD41-FITC (platelet marker) and annexin A5-Alexa Fluor 647 (PS exposure) and analyzed on an Amnis ImageStream Mark II (IS ${ }^{\mathrm{X}}$ ) multispectral imaging flow cytometer. Images representative of $n=4$ independent experiments.

It is still not clear why there is platelet response heterogeneity to becoming PS exposing. Certainly, it is not due to differences in overall platelet reactivity, as PS-exposing platelets express CD62P to the same extent as non-PS-exposing platelets (9), indicating that they are capable of the secretion event. Although it had previously been attributed to platelet age, with young platelets, identified by increased thiazole orange staining, having an enhanced capacity to take on a procoagulant phenotype $(22,97)$, uptake of this dye is increased in large platelets that are not necessarily young platelets in the steady state (98). Recently, it has been shown that young, newly produced, steadystate (rabbit) platelets are indeed less responsive in exposing PS than older platelets (98). It is speculated that differences in receptor expression levels and in $\mathrm{Ca}^{2+}$-flux machinery activity are involved (99), and levels of adhesive receptors, including GPVI, GPIb $\alpha, \alpha I I b$, and $\beta 3$, have been reported to be increased on procoagulant platelets $(97,100)$.

\section{Apoptosis-Induced Phosphatidylserine Exposure}

It is now well-recognized that platelets, although they are anucleate, can undergo apoptosis. This occurs via the intrinsic, mitochondrial-dependent pathway, with platelets possessing the necessary cytosolic machinery, while likely lacking the death receptors required for the extrinsic pathway $(37,101,102)$. Platelet apoptosis can be initiated in vitro by ABT-737, a BH3only protein mimetic, that inhibits the pro-survival Bcl-2 family protein $\mathrm{Bcl}-\mathrm{xL}$, resulting in activation of the proapoptotic $\mathrm{Bcl}-2$ proteins Bak and Bax; these then go on to initiate mitochondrial damage, cytochrome c release, caspase activation, PS exposure, and membrane blebbing and EV formation (37, 52, 101), all hallmarks of apoptosis in nucleated cells.

In contrast to platelet agonist-induced PS exposure, which occurs rapidly, apoptosis-induced PS exposure occurs more slowly, on the order of hours $(9,37,52,53)$. This apoptosis 
pathway is indeed Bak and Bax dependent, as platelets lacking these proteins do not externalize PS when incubated with ABT-737. It is also caspase dependent, as responses are abolished in the presence of a caspase inhibitor (52, 78). However, it does not require increases in $\mathrm{Ca}^{2+}$ cyt or calpain activity, which are necessary for agonist-induced PS exposure (52) (Agonist-Induced Phosphatidylserine Exposure) There is early mitochondrial outer membrane permeabilization (MOMP), followed by later IMM disruption concomitant with PS exposure (81): MPTP formation may not be involved, and $\Delta \Psi_{\mathrm{m}}$ depolarization may occur (52, 103-105). PS-exposing platelets take on a rounded morphology but maintain cytoplasmic components $(105,106)$; EV formation is not observed early on, but increases with time $(103,104,107)$.

ABT-737 treatment of platelets has also been reported to result in PS exposure on a second platelet population at a higher level, observed with agonist-induced PS exposure, than described above. PS exposure on this population is dependent on increases in $\mathrm{Ca}^{2+}{ }_{\text {cyt }}$ and TMEM16F but unlike agonist-induced PS exposure is dependent on caspase activation $(78,107)$.

Apoptosis, being the process of programmed cell death, is a major physiological mechanism that regulates the life span of cells, with externalized PS being the "eat me" recognition signal for phagocytic cells to mediate clearance of damaged cells (108). Platelet apoptosis regulates circulating platelet life span, as mutations in Bcl-xL result in shortened platelet survival, while deletion of Bak and Bax prolongs it by almost 2-fold $(109,110)$. Administration of ABT-737 to dogs and mice causes dramatic thrombocytopenia within $2 \mathrm{~h}(109,111)$, but PS exposure persists on the circulating platelets (106); formation of venous thrombi is inhibited (106). Platelet PS exposure may be involved in physiological platelet clearance; the proportion of PS-exposing platelets increases as rabbit platelets age in the circulation under steady-state conditions (77).

\section{PATHOLOGIES OF PHOSPHATIDYLSERINE EXPOSURE}

The importance of activated platelet membrane phospholipid bilayer scrambling with resulting PS exposure in hemostasis is highlighted in the very rare inherited autosomal recessive disorder Scott syndrome. The first-described patient, Mrs. M.A. Scott, had a relatively severe bleeding phenotype: she was found to have an isolated defect in PF3a (Introduction) (112); impaired PS exposure upon platelet activation, thereby resulting in deficient procoagulant activity and abrogated fibrin formation at sites of vascular damage $(3,113)$; and diminished EV formation (Agonist-Induced Phosphatidylserine Exposure) The genetic defect in four of the six known Scott syndrome patients for whom mutational analysis is available, as well as in canine Scott syndrome, in German Shepherd dogs, involves homozygous and heterozygous variants in the TMEM16F gene $(47,49,114-$ 118 ), resulting in an absence of expression of the TMEM16F protein (Scramblase and TMEM16F) Knockout of TMEM16F in genetically modified mice recapitulates the Scott syndrome phenotype (119-122).
Studies of Scott syndrome platelets have shown that, in humans, TMEM16F is required for the major agonist-induced PS exposure pathway but is not essential for apoptosis-induced PS exposure (78). In contrast, in dogs, both agonist- and apoptosisinduced platelet PS exposure requires TMEM16F (116). Detailed proteomic profiling of human Scott syndrome platelets has provided insight into protein modifications that occur when platelets are activated to expose PS (123).

In contrast with the Scott syndrome, in the rare autosomal dominant Stormorken syndrome, resting platelets have elevated surface PS exposure; resting $\mathrm{Ca}^{2+}$ cyt is increased due to a novel STIM1 gain-of-function variant. Stormorken syndrome patients have thrombocytopenia and a mild bleeding diathesis along with their thrombocytopathy (124).

Another inherited disorder in which elevated PS exposure and $\mathrm{Ca}^{2+}{ }_{\text {cyt }}$ is observed with resting platelets is the microthrombocytopenia, Wiskott-Aldrich syndrome (WAS) Upon stimulation, WAS platelets have increased susceptibility to PS exposure that occurs as a result of MPTP opening $(125,126)$.

Resting platelets from Bernard-Soulier syndrome patients also have elevated PS exposure, independent of their large size (127), indicating a role for GPIb-IX-V. PS exposure is generally increased in activated BSS platelets as well and is accompanied by $\Delta \Psi_{\mathrm{m}}$ depolarization in a proportion of platelets (127).

Aberrant PS exposure has been described in certain acquired platelet disorders. Platelets from patients with immune thrombocytopenia have increased (apoptosis-induced) PS exposure likely contributing to the decreased platelet counts $(128,129)$. Recently, there has been the report of increased circulating PS-exposing ballooned platelets in trauma hemorrhage in response to the damage-associated molecular pattern histone $\mathrm{H} 4$, demonstrating a mechanism by which platelets respond to tissue damage (130).

\section{CONCLUSION: POTENTIAL OF PROCOAGULANT PHOSPHATIDYLSERINE-EXPOSING PLATELETS AS AN ANTITHROMBOTIC TARGET}

Understanding of the mechanisms involved in the formation of the procoagulant PS-exposing platelet phenotype and its role in hemostasis has increased dramatically. Since traditional antiplatelet agents do not completely reduce the risk of thromboembolic events, the question arises: Is PS exposure a useful antithrombotic target? Not surprisingly, drugs that target the $\mathrm{ADP}$ and $\mathrm{TxA}_{2}$ pathways of platelet activation and aggregation have no major effect on inhibiting platelet procoagulant activity $(38,131,132)$ since these agonists are not particularly potent in stimulating the formation of PS-exposing platelets (Agonist-Induced Phosphatidylserine Exposure). There are certainly indications that the procoagulant platelet might be a useful target in reducing thrombosis. Firstly, knockout of TMEM16F in platelets of genetically 
modified mice (Pathologies of Phosphatidylserine Exposure) decreases platelet thrombus formation in vitro on collagencoated coverslips under flow conditions and in models of arterial and venous thrombosis (119-122). Secondly, there is evidence that in clinical conditions of thrombosis, specifically coronary artery disease, and essential thrombocythemia, the procoagulant platelet response is increased, and that increased levels of procoagulant platelets are associated with increased risk for recurrent infarction in lacunar and non-lacunar stroke and predict incident stroke after transient ischemic attack $(131,133-$ 136). Thirdly, procoagulant platelets have recently been shown to play a critical role in forming neutrophil macroaggregates that promote pulmonary thrombosis after gut ischemia that is a potent inducer of platelet PS exposure on the endothelium in the intestines, liver, and lungs; large membrane fragments ripped from PS-exposing platelets in a shear-dependent fashion wrap around the neutrophils to form adhesive bridges (137).

Thus, since PS exposure persists on activated platelets not only in vitro but in vivo as well $(76,94)$, blocking of the procoagulant surface could be an effective, novel strategy to reduce thrombosis. By binding to PS, annexin A5, diannexin

\section{REFERENCES}

1. Revel-Vilk S, Rand ML, Israels SJ. Primary and secondary hemostasis, regulators of coagulation, and fibrinolysis: understanding the basics. In: Blanchette VS, Brandao LR, Breakey VR, Revel-Vilk S, editors. SickKids Handbook of Pediatric Thrombosis and Hemostasis. 2nd ed, Basel: Karger (2017). p. 8-16. doi: 10.1159/000446684

2. Monroe DM, Hoffman M, Roberts HR. Platelets and thrombin generation. Arterioscler Thromb Vasc Biol. (2002) 22:1381-9. doi: 10.1161/01.ATV.0000031340.68494.34

3. Weiss HJ. Impaired platelet procoagulant mechanisms in patients with bleeding disorders. Semin Thromb Hemost. (2009) 35:233-41. doi: 10.1055/s-0029-1220331

4. Zwaal RF, Schroit AJ. Pathophysiologic implications of membrane phospholipid asymmetry in blood cells. Blood. (1997) 89:1121-32. doi: 10.1182/blood.V89.4.1121

5. Schreuder M, Reitsma PH, Bos MHA. Blood coagulation factor Va's key interactive residues and regions for prothrombinase assembly and prothrombin binding. J Thromb Haemost. (2019) 17:1229-39. doi: $10.1111 /$ jth. 14487

6. Gilbert GE, Novakovic VA, Kaufman RJ, Miao H, Pipe SW. Conservative mutations in the $\mathrm{C} 2$ domains of factor VIII and factor V alter phospholipid binding and cofactor activity. Blood. (2012) 120:1923-32. doi: 10.1182/blood-2012-01-408245

7. Zwaal RF, Comfurius P. and Bevers EM. Lipid-protein interactions in blood coagulation. Biochim Biophys Acta. (1998) 1376:433-53. doi: 10.1016/S0304-4157(98)00018-5

8. Heemskerk JW, Bevers EM, Lindhout T. Platelet activation and blood coagulation. Thromb Haemost. (2002) 88:186-93. doi: 10.1055/s-0037-1613209

9. Bevers EM, Williamson PL. Getting to the outer leaflet: physiology of phosphatidylserine exposure at the plasma membrane. Physiol Rev. (2016) 96:605-45. doi: 10.1152/physrev.00020.2015

10. Tavoosi N, Davis-Harrison RL, Pogorelov TV, Ohkubo YZ, Arcario MJ, Clay MC, et al. Molecular determinants of phospholipid synergy in blood clotting. J Biol Chem. (2011) 286:23247-53. doi: 10.1074/jbc.M111.251769

11. Clark SR, Thomas CP, Hammond VJ, Aldrovandi M, Wilkinson GW, Hart KW, et al. Characterization of platelet aminophospholipid externalization reveals fatty acids as molecular determinants that regulate coagulation. Proc Natl Acad Sci USA. (2013) 110:5875-80. doi: 10.1073/pnas.1222419110 [a recombinant annexin A5 homodimer with a longer circulating half-life than annexin A5 and a 10-fold higher binding affinity to PS $(138,139)]$ and lactadherin inhibit thrombus formation in vitro and in animal models of arterial and venous thrombosis (139-145). However, diannexin and lactadherin impair hemostasis as well, increasing murine tail bleeding time blood loss $(139,145)$; thus, if a strategy of blocking exposed PS is to be pursued, dosages of blocking compounds must be finely tuned.

Alternatively, mitochondrial depolarization (70), scramblase activity $(146,147)$, or water entry into platelets $(33,148)$ are potential targets to inhibit formation of the thrombin-generating subpopulation of platelets while still allowing platelet aggregation to occur. It may be that inhibition of procoagulant platelet formation could be an alternative approach to reduce thrombosis without impairing hemostasis.

\section{AUTHOR CONTRIBUTIONS}

All authors listed have made a substantial, direct and intellectual contribution to the work, and approved it for publication.

12. Lauder SN, Allen-Redpath K, Slatter DA, Aldrovandi M, O'Connor A, Farewell D, et al. Networks of enzymatically oxidized membrane lipids support calcium-dependent coagulation factor binding to maintain hemostasis. Sci Signal. (2017) 10:eaan2787. doi: 10.1126/scisignal. aan 2787

13. Camera M, Toschi V, Brambilla M, Lettino M, Rossetti L, Canzano P, et al. The role of tissue factor in atherothrombosis and coronary artery disease: insights into platelet tissue factor. Semin Thromb Hemost. (2015) 41:737-46. doi: 10.1055/s-0035-1564041

14. Brambilla M, Facchinetti L, Canzano P, Rossetti L, Ferri N, Balduini A, et al. Camera: human megakaryocytes confer tissue factor to a subset of shed platelets to stimulate thrombin generation. Thromb Haemost. (2015) 114:579-92. doi: 10.1160/TH14-10-0830

15. Panes O, González C, Hidalgo P, Valderas JP, Acevedo M, Contreras $\mathrm{S}$, et al. Platelet tissue factor activity and membrane cholesterol are increased in hypercholesterolemia and normalized by rosuvastatin, but not by atorvastatin. Atherosclerosis. (2017) 257:164-171. doi: 10.1016/j.atherosclerosis.2016.12.019

16. Matus V, Valenzuela JG, Hidalgo P, Pozo LM, Panes O, Wozniak A. Human platelet interaction with $E$. coli $\mathrm{O} 111$ promotes tissue-factor-dependent procoagulant activity, involving Toll like receptor 4. PLoS ONE. (2017) 12:e185431. doi: 10.1371/journal.pone.0185431

17. Brambilla M, Gelosa P, Rossetti L, Castiglioni L, Zara C, Canzano P, et al. Impact of angiotensin-converting enzyme inhibition on platelet tissue factor expression in stroke-prone rats. J Hypertens. (2018) 36:1360-1371. doi: 10.1097/HJH.0000000000001702

18. Capozzi A, Manganelli V, Riitano G, Recalchi S, Truglia S, Alessandri C, et al. Tissue factor over-expression in platelets of patients with anti-phospholipid syndrome: induction role of anti- $\beta 2-$ GPI antibodies. Clin Exp Immunol. (2019) 196:59-66. doi: 10.1111/cei.13248

19. Dachary-Prigent J, Freyssinet JM, Pasquet JM, Carron JC, Nurden AT. Annexin $\mathrm{V}$ as a probe of aminophospholipid exposure and platelet membrane vesiculation: a flow cytometry study showing a role for free sulfhydryl groups. Blood. (1993) 81:2554-65. doi: 10.1182/blood.V81.10.2554.2554

20. Dasgupta SK, Guchhait P, Thiagarajan P. Lactadherin binding and phosphatidylserine expression on cell surface-comparison with annexin A5. Transl Res. (2006) 148:19-25. doi: 10.1016/j.lab.2006.03.006

21. Podoplelova NA, Sveshnikova AN, Kotova YN, Eckly A, Receveur N, Nechipurenko DY, et al. Coagulation factors bound to procoagulant platelets 
concentrate in cap structures to promote clotting. Blood. (2016) 128:1745-55. doi: 10.1182/blood-2016-02-696898

22. Alberio A, Safa O, Clemetson KJ, Esmon CT, Dale GL. Surface expression and functional characterization of alpha-granule factor $\mathrm{V}$ in human platelets: effects of ionophore A23187, thrombin, collagen, and convulxin. Blood. (2000) 95:1694-702. doi: 10.1182/blood.V95.5.1694.005k24_1694_1702

23. Heemskerk JW, Mattheij NJ, Cosemans JM. Platelet-based coagulation: different populations, different functions. J Thromb Haemost. (2013) 11:216. doi: $10.1111 /$ jth. 12045

24. Swieringa F, Spronk HHM, Heemskerk JWM, van der Meijden JPE. Integrating platelet and coagulation activation in fibrin clot formation. Res Pract Thromb Haemost. (2018) 2:450-460. doi: 10.1002/rth2.12107

25. London FS, Marcinkiewicz M, Walsh PN. A subpopulation of platelets responds to thrombin- or SFLLRN-stimulation with binding sites for factor IXa. J Biol Chem. (2004) 279:19854-9. doi: 10.1074/jbc.M310624200

26. Alberio LJ, Clemetson KJ. All platelets are not equal: COAT platelets. Curr Hematol Rep. (2004) 3:338-43

27. Dale GL, Friese P, Batar P, Hamilton SF, Reed GL, Jackson KW, et al. Stimulated platelets use serotonin to enhance their retention of procoagulant proteins on the cell surface. Nature. (2002) 415:175-9. doi: 10.1038/415175a

28. Dale GL. Coated-platelets: an emerging component of the procoagulant response. J Thromb Haemost. (2005) 3:2185-92. doi: 10.1111/j.1538-7836.2005.01274.x

29. Mattheij NJ, Swieringa F, Mastenbroek TG, Berny-Lang MA, May F, Baaten $\mathrm{CC}$, et al. Coated platelets function in platelet-dependent fibrin formation via integrin $\alpha_{I I b} \beta_{3}$ and transglutaminase factor XIII. Haematologica. (2016) 101:427-36. doi: 10.3324/haematol.2015.131441

30. van der Meijden JPE, Heemskerk MJW. Platelet biology and functions: new concepts and clinical perspectives. Nat Rev Cardiol. (2019) 16:166-179. doi: 10.1038/s41569-018-0110-0

31. Heemskerk JW, Vuist WM, Feijge MA, Reutelingsperger CP, Lindhout T. Collagen but not fibrinogen surfaces induce bleb formation, exposure of phosphatidylserine, and procoagulant activity of adherent platelets: evidence for regulation by protein tyrosine kinase-dependent Ca2+ responses. Blood. (1997) 90:2615-25. doi: 10.1182/blood.V90.7.2615.2615_2615_2625

32. Munnix IC, Kuijpers MJ, Auger J, Thomassen CM, Panizzi P, van MA, et al. Segregation of platelet aggregatory and procoagulant microdomains in thrombus formation: regulation by transient integrin activation. Arterioscler Thromb Vasc Biol. (2007) 27:2484-90. doi: 10.1161/ATVBAHA.107.151100

33. Agbani EO, den Bosch VMT, Brown E, Williams CM, Mattheij NJ, Cosemans JM, et al. Coordinated membrane ballooning and procoagulant spreading in human platelets. Circulation. (2015) 132:1414-24. doi: 10.1161/CIRCULATIONAHA.114.015036

34. Hess MW, Siljander P. Procoagulant platelet balloons: evidence from cryopreparation and electron microscopy. Histochem Cell Biol. (2001) 115:439-43. doi: 10.1007/s004180100272

35. Reddy EC, Wang H, Christensen H, McMillan-Ward E, Israels SJ, Bang KWA, et al. Analysis of procoagulant phosphatidylserine-exposing platelets by imaging flow cytometry. Res Pract Thromb Haemost. (2018) 2:736-750. doi: $10.1002 / \mathrm{rth} 2.12144$

36. Kulkarni S, Jackson SP. Platelet factor XIII and calpain negatively regulate integrin alphaIIbbeta3 adhesive function and thrombus growth. J Biol Chem. (2004) 279:30697-706. doi: 10.1074/jbc.M403559200

37. Jackson SP, Schoenwaelder SM. Procoagulant platelets: are they necrotic? Blood. (2010) 116:2011-8. doi: 10.1182/blood-2010-01-261669

38. Hua VM, Abeynaike L, Glaros E, Campbell H, Pasalic L, Hogg PJ, et al. Necrotic platelets provide a procoagulant surface during thrombosis. Blood. (2015) 126:2852-62. doi: 10.1182/blood-2015-08-663005

39. Hua VM, Chen VM. Procoagulant platelets and the pathways leading to cell death. Semin Thromb Hemost. (2015) 41:405-12. doi: 10.1055/s-0034-1544002

40. Mazepa M, Hoffman M, Monroe D. Superactivated platelets: thrombus regulators, thrombin generators, and potential clinical targets. Arterioscler Thromb Vasc Biol. (2013) 33:1747-52. doi: 10.1161/ATVBAHA.113.301790

41. Abaeva AA, Canault M, Kotova YN, Obydennyy SI, Yakimenko AO, Podoplelova NA, et al. Procoagulant platelets form an $\alpha$-granule proteincovered "cap" on their surface that promotes their attachment to aggregates. J Biol Chem. (2013) 288:29621-32. doi: 10.1074/jbc.M113.474163
42. Storrie B. A tip of the cap to procoagulant platelets. Blood. (2016) 128:1668-9. doi: 10.1182/blood-2016-08-730622

43. Agbani EO, Poole AW. Procoagulant platelets: generation, function, and therapeutic targeting in thrombosis. Blood. (2017) 130:2171-2179. doi: 10.1182/blood-2017-05-787259

44. Segawa K, Kurata S, Nagata S. Human Type IV P-type ATPases that work as plasma membrane phospholipid flippases and their regulation by caspase and calcium. J Biol Chem. (2016) 291:762-72. doi: 10.1074/jbc.M115.690727

45. Beleznay Z, Zachowski A, Devaux PF, Navazo MP, Ott P. ATP-dependent aminophospholipid translocation in erythrocyte vesicles: stoichiometry of transport. Biochemistry. (1993) 32:3146-52. doi: 10.1021/bi00063a029

46. Bitbol M, Fellmann P, Zachowski P, Devaux PF. Ion regulation of phosphatidylserine and phosphatidylethanolamine outside-inside translocation in human erythrocytes. Biochim Biophys Acta. (1987) 904:268-82. doi: 10.1016/0005-2736(87)90376-2

47. Suzuki J, Umeda M, Sims PJ, Nagata S. Calcium-dependent phospholipid scrambling by TMEM16F. Nature. (2010) 468:834-8. doi: $10.1038 /$ nature 09583

48. Lhermusier T, Chap H, Payrastre B. Platelet membrane phospholipid asymmetry: from the characterization of a scramblase activity to the identification of an essential protein mutated in Scott syndrome. J Thromb Haemost. (2011) 9:1883-91. doi: 10.1111/j.1538-7836.2011. 04478.x

49. Kunzelmann K, Nilius B, Owsianik G, Schreiber R, Ousingsawat J, Sirianant L, et al. Molecular functions of anoctamin 6 (TMEM16F): a chloride channel, cation channel, or phospholipid scramblase? Pflugers Arch. (2014) 466:40714. doi: 10.1007/s00424-013-1305-1

50. Watanabe R, Sakuragi T, Noji H, Nagata S. Single-molecule analysis of phospholipid scrambling by TMEM16F. Proc Natl Acad Sci USA. (2018) 115:3066-71. doi: 10.1073/pnas.1717956115

51. Le T, Jia Z, Le SC, Zhang Y, Chen J, Yang H. An inner activation gate controls TMEM16F phospholipid scrambling. Nat Commun. (2019) 10:1846. doi: 10.1038/s41467-019-09778-7

52. Schoenwaelder SM, Yuan Y, Josefsson EC, White MJ, Yao Y, Mason $\mathrm{KD}$, et al. Two distinct pathways regulate platelet phosphatidylserine exposure and procoagulant function. Blood. (2009) 114:663-6. doi: 10.1182/blood-2009-01-200345

53. Zwaal RF, Comfurius P, Bevers EM. Surface exposure of phosphatidylserine in pathological cells. Cell Mol Life Sci. (2005) 62:971-88. doi: 10.1007/s00018-005-4527-3

54. Yang M, Kholmukhamedov A, Schulte ML, Cooley BC, Scoggins NO, Wood JP, et al. Platelet CD36 signaling through ERK5 promotes caspasedependent procoagulant activity and fibrin deposition in vivo. Blood Adv. (2018) 2:2848-61. doi: 10.1182/bloodadvances.2018025411

55. Abbasian N, Millington-Burgess SL, Chabra S, Malcor JD, Harper MT. Supramaximal calcium signaling triggers procoagulant platelet formation. Blood Adv. (2020) 4:154-64. doi: 10.1182/bloodadvances.2019000182

56. Wolfs JL, Comfurius P, Rasmussen JT, Keuren JF, Lindhout T, Zwaal RF, et al. Activated scramblase and inhibited aminophospholipid translocase cause phosphatidylserine exposure in a distinct platelet fraction. Cell Mol Life Sci. (2005) 62:1514-25. doi: 10.1007/s00018-005-5099-y

57. Leytin V, Allen DJ, Mykhaylov S, Mis L, Lyubimov EV, Garvey $\mathrm{B}$, et al. Pathologic high shear stress induces apoptosis events in human platelets. Biochem Biophys Res Commun. (2004) 320:303-10. doi: 10.1016/j.bbrc.2004.05.166

58. Pang A, Cui Y, Chen Y, Cheng N, Delaney MK, Gu M, et al. Shearinduced integrin signaling in platelet phosphatidylserine exposure, microvesicle release, and coagulation. Blood. (2018) 132:533-43. doi: 10.1182/blood-2017-05-785253

59. Harper MT, Molkentin JD, Poole AW. Protein kinase C alpha enhances sodium-calcium exchange during store-operated calcium entry in mouse platelets. Cell Calcium. (2010) 48:333-40. doi: 10.1016/j.ceca.2010.10.006

60. Alberio L, Ravanat C, Hechler B, Mangin PH, Lanza F, Gachet C. Delayed-onset of procoagulant signalling revealed by kinetic analysis of COAT platelet formation. Thromb Haemost. (2017) 117:1101-14. doi: 10.1160/TH16-09-0711

61. Harper MT, Londoño JE, Quick K, Londoño JC, Flockerzi V, Philipp SE, et al. Transient receptor potential channels function as a coincidence signal 
detector mediating phosphatidylserine exposure. Sci Signal. (2013) 6:ra50. doi: 10.1126/scisignal.2003701

62. Croce K, Flaumenhaft R, Rivers M, Furie B, Furie BC, Herman IM, et al. Inhibition of calpain blocks platelet secretion, aggregation, and spreading. $J$ Biol Chem. (1999) 274:36321-7. doi: 10.1074/jbc.274.51.36321

63. Schoenwaelder SM, Yuan Y, Jackson SP. Calpain regulation of integrin alpha IIb beta 3 signaling in human platelets. Platelets. (2000) 11:189-98. doi: $10.1080 / 09537100050057620$

64. Fox JE. Cytoskeletal proteins and platelet signaling. Thromb Haemost. (2001) 86:198-213.doi: 10.1055/s-0037-1616218

65. Mattheij NJ, Gilio K, van Kruchten R, Jobe SM, Wieschhaus AJ, Chishti $\mathrm{AH}$, et al. Dual mechanism of integrin $\alpha \mathrm{IIb} \beta 3$ closure in procoagulant platelets. J Biol Chem. (2013) 288:13325-36. doi: 10.1074/jbc.M112.4 28359

66. Nechipurenko DY, Receveur N, Yakimenko AO, Shepelyuk TO, Yakusheva $\mathrm{AA}$, Kerimov RR, et al. Clot contraction drives the translocation of procoagulant platelets to thrombus surface. Arterioscler Thromb Vasc Biol. (2019) 39:37-47. doi: 10.1161/ATVBAHA.118.311390

67. Baines CP, Kaiser RA, Purcell NH, Blair NS, Osinska H, Hambleton MA, et al. Loss of cyclophilin D reveals a critical role for mitochondrial permeability transition in cell death. Nature. (2005) 434:658-62. doi: 10.1038/ nature 03434

68. Basso E, Fante L, Fowlkes J, Petronilli V, Forte MA, Bernardi P. Properties of the permeability transition pore in mitochondria devoid of Cyclophilin D. $J$ Biol Chem. (2005) 280:18558-61. doi: 10.1074/jbc.C500089200

69. Jobe SM, Wilson KM, Leo L, Raimondi A, Molkentin JD, Lentz SR, et al. Critical role for the mitochondrial permeability transition pore and Cyclophilin D in platelet activation and thrombosis. Blood. (2008) 111:125765. doi: 10.1182/blood-2007-05-092684

70. Choo HJ, Saafir TB, Mkumba L, Wagner MB, Jobe SM. Mitochondrial calcium and reactive oxygen species regulate agonist-initiated platelet phosphatidylserine exposure. Arterioscler Thromb Vasc Biol. (2012) 32:294655. doi: 10.1161/ATVBAHA.112.300433

71. Remenyi G, Szasz R, Friese P, Dale GL. Role of mitochondrial permeability transition pore in coated-platelet formation. Arterioscler Thromb Vasc Biol. (2005) 25:467-71. doi: 10.1161/01.ATV.0000152726.49229.bf

72. Petit PX, Zamzami N, Vayssière JL, Mignotte B, Kroemer G, Castedo M. Implication of mitochondria in apoptosis. Mol Cell Biochem. (1997) 174:1858. doi: 10.1007/978-1-4615-6111-8_28

73. Halestrap AP, McStay GP, Clarke SJ. The permeability transition pore complex: another view. Biochimie. (2002) 84:153-66. doi: 10.1016/S0300-9084(02)01375-5

74. Leytin V, Freedman J. Platelet apoptosis in stored platelet concentrates and other models. Transfus Apher Sci. (2003) 28:285-95. doi: 10.1016/S1473-0502(03)00048-X

75. Leytin V, Allen DJ, Mykhaylov S, Lyubimov E, Freedman J. Thrombintriggered platelet apoptosis. J Thromb Haemost. (2006) 4:2656-63. doi: 10.1111/j.1538-7836.2006.02200.x

76. Leung R, Gwozdz AM, Wang H, Bang KW, Packham MA, Freedman J, et al. Persistence of procoagulant surface expression on activated human platelets: involvement of apoptosis and aminophospholipid translocase activity. J Thromb Haemost. (2007) 5:560-70. doi: 10.1111/j.1538-7836.2007. 02354.x

77. Rand ML, Wang H, Bang KW, Poon KS, Packham MA, Freedman J. Procoagulant surface exposure and apoptosis in rabbit platelets: association with shortened survival and steady-state senescence. J Thromb Haemost. (2004) 2:651-9. doi: 10.1111/j.1538-7836.2004.00670.x

78. van Kruchten R, Mattheij NJ, Saunders C, Feijge MA, Swieringa F, Wolfs JL, et al. Both TMEM16F-dependent and TMEM16F-independent pathways contribute to phosphatidylserine exposure in platelet apoptosis and platelet activation. Blood. (2013) 121:1850-7. doi: 10.1182/blood-2012-09454314

79. Leytin V, Allen DJ, Mutlu A, Gyulkhandanyan AV, Mykhaylov S, Freedman J. Mitochondrial control of platelet apoptosis: effect of cyclosporin A, an inhibitor of the mitochondrial permeability transition pore. Lab Invest. (2009) 89:374-84. doi: 10.1038/labinvest.2009.13

80. Topalov NN, Yakimenko AO, Canault M, Artemenko EO, Zakharova NV, Abaeva AA, et al. Two types of procoagulant platelets are formed upon physiological activation and are controlled by integrin $\alpha_{I I b} \beta_{3}$. Arterioscler Thromb Vasc Biol. (2012) 32:2475-83. doi: 10.1161/ATVBAHA.112.253765

81. Choo HJ, Kholmukhamedov A, Zhou C, Jobe S. Inner mitochondrial membrane disruption links apoptotic and agonist-initiated phosphatidylserine externalization in platelets. Arterioscler Thromb Vasc Biol. (2017) 37:1503-12. doi: 10.1161/ATVBAHA.117. 309473

82. Wolf BB, Goldstein JC, Stennicke HR, Beere H, Amarante-Mendes GP, Salvesen GS, et al. Calpain functions in a caspase-independent manner to promote apoptosis-like events during platelet activation. Blood. (1999) 94:1683-92. doi: 10.1182/blood.V94.5.1683

83. Baaten FCCM, Swieringa F, Misztal T, Mastenbroek TG, Feijge HMA, Bock PE, et al. Platelet heterogeneity in activation-induced glycoprotein shedding: functional effects. Blood Adv. (2018) 2:2320-31. doi: 10.1182/bloodadvances.2017011544

84. Gerrard JM, White JG, Rao GH. Effects of the lonophore A23187 on the blood platelets II. Influence on ultrastructure. Am J Pathol. (1974) 77:151-66.

85. Agbani EO, Hers I, Poole AW. Temporal contribution of the platelet body and balloon to thrombin generation. Haematologica. (2017) 102:e379-81. doi: 10.3324/haematol.2017.166819

86. Gasecka A, Nieuwland R, Siljander PR-M. Platelet-derived extracellular vesicles. In: A. Michelson, M. Cattaneo, A. Frelinger and P. Newman editors. Platelets 4th ed. London: Academic Press Platelets (2019). p. 401-16. doi: 10.1016/B978-0-12-813456-6.00022-9

87. Sims PJ, Wiedmer T., Esmon CT, Weiss HJ, Shattil SJ. Assembly of the platelet prothrombinase complex is linked to vesiculation of the platelet plasma membrane. studies in scott syndrome: an isolated defect in platelet procoagulant activity. J Biol Chem. (1989) 264:17049-57.

88. Weiss HJ. Scott syndrome: a disorder of platelet coagulant activity. Semin Hematol. (1994) 31:312-9.

89. Boilard E, Duchez AC, Brisson A. The diversity of platelet microparticles. Curr Opin Hematol. (2015) 22:437-44. doi: 10.1097/MOH.0000000000000166

90. Ponomareva AA, Nevzorova TA, Mordakhanova ER, Andrianova IA, Rauova L, Litvinov RI, et al. Intracellular origin and ultrastructure of platelet-derived microparticles. J Thromb Haemost. (2017) 15:1655-67. doi: $10.1111 /$ th. 13745

91. Boilard E, Nigrovic PA, Larabee K, Watts GF, Coblyn JS, Weinblatt $\mathrm{ME}$, et al. Platelets amplify inflammation in arthritis via collagendependent microparticle production. Science. (2010) 327:580-3. doi: $10.1126 /$ science.1181928

92. Rand ML, Wang H, Bang KW, Packham MA, Freedman J. Rapid clearance of procoagulant platelet-derived microparticles from the circulation of rabbits. J Thromb Haemost. (2006) 4:1621-3. doi: 10.1111/j.1538-7836.2006. 02011.x

93. Södergren AL, Ramström S. Platelet subpopulations remain despite strong dual agonist stimulation and can be characterised using a novel six-colour flow cytometry protocol. Sci Rep. (2018) 8:1441. doi: 10.1038/s41598-017-19126-8

94. Rand ML, Wang H, Bang KW, Packham MA, Freedman J. Persistence of phosphatidylserine exposure on activated platelets in vivo in rabbits. Thromb Haemost. (2007) 98:477-8. doi: 10.1160/TH0612-0702

95. Segawa K, Suzuki J, Nagata S. Constitutive exposure of phosphatidylserine on viable cells. Proc Natl Acad Sci USA. (2011) 108:19246-51. doi: $10.1073 /$ pnas. 1114799108

96. Dillon SR, Mancini M, Rosen A, Schlissel MS. Annexin V binds to viable $\mathrm{B}$ cells and colocalizes with a marker of lipid rafts upon B cell receptor activation. I Immunol. (2000) 164:1322-32. doi: 10.4049/jimmunol.164.3.1322

97. Fager AM, Wood JP, Bouchard BA, Feng P, Tracy PB. Properties of procoagulant platelets: defining and characterizing the subpopulation binding a functional prothrombinase. Arterioscler Thromb Vasc Biol. (2010) 30:2400-7. doi: 10.1161/ATVBAHA.110.216531

98. Reddy EC, Wang H, Bang AKW, Packham MA, Rand ML. Young steady-state rabbit platelets do not have an enhanced capacity to expose procoagulant phosphatidylserine. Platelets. (2018) 29:27-33. doi: $10.1080 / 09537104.2017 .1295434$ 
99. Baaten CCMJ, Ten Cate H, van der Meijden JPE, Heemskerk JWM. Platelet populations and priming in hematological diseases. Blood Rev. (2017) 31:389-99. doi: 10.1016/j.blre.2017.07.004

100. Furihata K, Clemetson KJ, Deguchi H, Kunicki TJ. Variation in human platelet glycoprotein VI content modulates glycoprotein VI-specific prothrombinase activity. Arterioscler Thromb Vasc Biol. (2001) 21:1857-63. doi: 10.1161/hq1001.096643

101. Leytin V. Apoptosis in the anucleate platelet. Blood Rev. (2012) 26:51-63. doi: 10.1016/j.blre.2011.10.002

102. Winkler J, Rand ML, Schmugge M, Speer O. Omi/HtrA2 and XIAP are components of platelet apoptosis signalling. Thromb Haemost. (2013) 109:532-9. doi: 10.1160/TH12-06-0404

103. Gyulkhandanyan AV, Mutlu A, Allen DJ, Freedman J, Leytin V. BH3mimetic ABT-737 induces strong mitochondrial membrane depolarization in platelets but only weakly stimulates apoptotic morphological changes, platelet shrinkage and microparticle formation. Thromb Res. (2014) 133:739. doi: 10.1016/j.thromres.2013.10.041

104. Gyulkhandanyan AV, Mutlu A, Freedman J, Leytin V. Mitochondrial permeability transition pore (MPTP)-dependent and -independent pathways of mitochondrial membrane depolarization, cell shrinkage and microparticle formation during platelet apoptosis. Br J Haematol. (2015) 169:142-5. doi: 10.1111/bjh.13180

105. Vogler M, Hamali HA, Sun XM, Bampton ET, Dinsdale D, Snowden RT, et al. BCL2/BCL-X(L) inhibition induces apoptosis, disrupts cellular calcium homeostasis, and prevents platelet activation. Blood. (2011) 117:7145-54. doi: 10.1182/blood-2011-03-344812

106. Schoenwaelder SM, Jarman KE, Gardiner EE, Hua M, Qiao J, White MJ, et al. $\mathrm{Bcl}-\mathrm{xL}$-inhibitory $\mathrm{BH} 3$ mimetics can induce a transient thrombocytopathy that undermines the hemostatic function of platelets. Blood. (2011) 118:1663-74. doi: 10.1182/blood-2011-04-347849

107. Wei H, Harper MT. ABT-737 triggers caspase-dependent inhibition of platelet procoagulant extracellular vesicle release during apoptosis and secondary necrosis in vitro. Thromb Haemost. (2019) 19:1665-74. doi: 10.1055/s-0039-1693694

108. Segawa K, Nagata S. An apoptotic "eat me" signal: phosphatidylserine exposure. Trends Cell Biol. (2015) 25:639-50. doi: 10.1016/j.tcb.2015.08.003

109. Mason KD, Carpinelli MR, Fletcher JI, Collinge JE, Hilton AA, Ellis S, et al. Programmed anuclear cell death delimits platelet life span. Cell. (2007) 128:1173-86. doi: 10.1016/j.cell.2007.01.037

110. Kile BT. The role of the intrinsic apoptosis pathway in platelet life and death. J Thromb Haemost. (2009) 7(Suppl.1):214-7. doi: 10.1111/j.1538-7836.2009.03366.x

111. Zhang H, Nimmer PM, Tahir SK, Chen J, Fryer RM, Hahn KR, et al. Bcl2 family proteins are essential for platelet survival. Cell Death Differ. (2007) 14:943-51. doi: 10.1038/sj.cdd.4402081

112. Weiss HJ, Vicic WJ, Lages BA, Rogers J. Isolated deficiency of platelet procoagulant activity. Am J Med. (1979) 67:206-13. doi: 10.1016/0002-9343(79)90392-9

113. Zwaal RF, Comfurius P. Bevers EM. Scott syndrome, a bleeding disorder caused by defective scrambling of membrane phospholipids. Biochim Biophys Acta. (2004) 1636:119-28. doi: 10.1016/j.bbalip.2003.07.003

114. Castoldi E, Collins PW, Williamson PL, Bevers EM. Compound heterozygosity for 2 novel TMEM16F mutations in a patient with scott syndrome. Blood. (2011) 117:4399-40. doi: 10.1182/blood-2011-01332502

115. Boisseau P, Bene MC, Besnard T, Pachchek S, Giraud M, Talarmain P, et al. A new mutation of ANO6 in two familial cases of Scott syndrome. $\mathrm{Br} \mathrm{J}$ Haematol. (2018) 180:750-2. doi: 10.1111/bjh.14439

116. Brooks MB, Catalfamo JL, MacNguyen R, Tim D, Fancher S, McCardle JA. A TMEM16F point mutation causes an absence of canine platelet TMEM16F and ineffective activation and death-induced phospholipid scrambling. $J$ Thromb Haemost. (2015) 13:2240-52. doi: 10.1111/jth.13157

117. Flores-Nascimento MC, Orsi FL, Yokoyama AP, Pereira FG, Lorand-Metze I, De EV, et al. Diagnosis of Scott syndrome in patient with bleeding disorder of unknown cause. Blood Coagul Fibrinolysis. (2012) 23:75-7. doi: 10.1097/MBC.0b013e32834d0c81

118. Millington-Burgess SL, Harper MT. Gene of the issue. Platelets. (2019) 1-4. doi: 10.1080/09537104.2019.1693039
119. Yang H, Kim A, David T, Palmer D, Jin T, Tien J, et al. TMEM16F forms a $\mathrm{Ca} 2+$-activated cation channel required for lipid scrambling in platelets during blood coagulation. Cell. (2012) 151:111-22. doi: 10.1016/j.cell.2012.07.036

120. Fujii T, Sakata A, Nishimura S, Eto K, Nagata S. TMEM16F is required for phosphatidylserine exposure and microparticle release in activated mouse platelets. Proc Natl Acad Sci USA. (2015) 112:12800-5. doi: 10.1073/pnas.1516594112

121. Mattheij NJ, Braun A, van Kruchten R, Castoldi E, Pircher J, Baaten CC, et al. Survival protein anoctamin- 6 controls multiple platelet responses including phospholipid scrambling, swelling, and protein cleavage. FASEB J. (2016) 30:727-37. doi: 10.1096/fj.15-280446

122. Baig AA, Haining EJ, Geuss E, Beck S, Swieringa F, Wanitchakool P, et al. Nieswandt: TMEM16F-mediated platelet membrane phospholipid scrambling is critical for hemostasis and thrombosis but not thromboinflammation in mice-brief report. Arterioscler Thromb Vasc Biol. (2016) 36:2152-7. doi: 10.1161/ATVBAHA.116.307727

123. Solari FA, Mattheij NJ, Burkhart JM, Swieringa F, Collins PW, Cosemans JM, et al. Combined quantification of the global proteome, phosphoproteome, and proteolytic cleavage to characterize altered platelet functions in the human scott syndrome. Mol Cell Proteomics. (2016) 15:3154-69. doi: 10.1074/mcp.M116.060368

124. Misceo D, Holmgren A, Louch WE, Holme PA, Mizobuchi M, Morales RJ, et al. A dominant STIM1 mutation causes Stormorken syndrome. Hum Mutat. (2014) 35:556-64. doi: 10.1002/humu.22544

125. Shcherbina A, Rosen FS, Remold-O'Donnell E. Pathological events in platelets of Wiskott-Aldrich syndrome patients. Br J Haematol. (1999) 106:875-83. doi: 10.1046/j.1365-2141.1999.01637.x

126. Obydennyi SI, Artemenko EO, Sveshnikova AN, Ignatova AA, Varlamova TV, Gambaryan S, et al. Mechanisms of increased mitochondria-dependent necrosis in Wiskott-Aldrich syndrome platelets. Haematologica. (2019) 2018:214460. doi: 10.3324/haematol.2018.214460

127. Rand ML, Wang H, Bang KW, Teitel JM, Blanchette VS, Freedman J, et al. Phosphatidylserine exposure and other apoptotic-like events in Bernard-Soulier syndrome platelets. Am J Hematol. (2010) 85:584-92. doi: 10.1002/ajh.21768

128. Catani L, Fagioli ME, Tazzari PL, Ricci F, Curti A, Rovito M, et al. Dendritic cells of immune thrombocytopenic purpura (ITP) show increased capacity to present apoptotic platelets to Tlymphocytes. Exp Hematol. (2006) 34:879-87. doi: 10.1016/j.exphem.2006.03.009

129. Winkler J, Kroiss S, Rand ML, Azzouzi I, Annie Bang KW, Speer O, et al. Platelet apoptosis in paediatric immune thrombocytopenia is ameliorated by intravenous immunoglobulin. $\mathrm{Br} J$ Haematol. (2012) 156:508-15. doi: 10.1111/j.1365-2141.2011.08973.x

130. Vulliamy P, Gillespie S, Armstrong PC, Allan HE, Warner TD, Brohi $\mathrm{K}$. Histone $\mathrm{H} 4$ induces platelet ballooning and microparticle release during trauma hemorrhage. Proc Natl Acad Sci USA. (2019) 116:17444-9. doi: 10.1073/pnas.1904978116

131. Pasalic L, Wing-Lun E, Lau JK, Campbell H, Pennings GJ, Lau E, et al. Novel assay demonstrates that coronary artery disease patients have heightened procoagulant platelet response. J Thromb Haemost. (2018) 16:1198-210. doi: $10.1111 /$ jth. 14008

132. Agbani EO, Williams CM, Hers I, Poole AW. Membrane ballooning in aggregated platelets is synchronised and mediates a surge in microvesiculation. Sci Rep. (2017) 7:2770. doi: 10.1038/s41598-01702933-4

133. Prodan CI, Stoner JA, Cowan LD, Dale GL. Higher coated-platelet levels are associated with stroke recurrence following non-lacunar brain infarction. $J$ Cereb Blood Flow Metab. (2013) 33:287-92. doi: 10.1038/jcbfm.2012.168

134. Kirkpatrick AC, Tafur AJ, Vincent AS, Dale GL, Prodan CI. Coatedplatelets improve prediction of stroke and transient ischemic attack in asymptomatic internal carotid artery stenosis. Stroke. (2014) 45:2995-3001. doi: 10.1161/STROKEAHA.114.006492

135. Tan CW, Wong WH, Campbell H, Cheong MA, Cheng J, Tohidi-Esfahani I, et al. Novel assay demonstrates increased procoagulant platelet response in essential thrombocythemia segregating with JAK2V617F mutation status and thrombosis. Res Pract Thromb Haemost. (2019) 3(Suppl.1):168-9. doi: $10.1002 /$ rth2.12227 
136. Kirkpatrick AC, Vincent AS, Dale GL, Prodan CI. Increased platelet procoagulant potential predicts recurrent stroke and TIA after lacunar infarction. J Thromb Haemost. (2019). doi: 10.1111/jth.14714. [Epub ahead of print].

137. Yuan Y, Alwis I, Wu LMC, Kaplan Z, Ashworth K, Bark D, et al. Neutrophil macroaggregates promote widespread pulmonary thrombosis after gut ischemia. Sci Transl Med. (2017) 9:aam5861. doi: 10.1126/scitranslmed.aam5861

138. Kuypers FA, Larkin SK, Emeis JJ, Allison AC. Interaction of an annexin $\mathrm{V}$ homodimer (Diannexin) with phosphatidylserine on cell surfaces and consequent antithrombotic activity. Thromb Haemost. (2007) 97:478-86. doi: 10.1160/TH06-08-0436

139. Rand ML, Wang H, Pluthero FG, Stafford AR, Ni R, Vaezzadeh N, et al. Diannexin, an annexin A5 homodimer, binds phosphatidylserine with high affinity and is a potent inhibitor of platelet-mediated events during thrombus formation. J Thromb Haemost. (2012) 10:1109-19. doi: 10.1111/j.1538-7836.2012.04716.x

140. Galán AM, van Heerde WL, Escolar G, Ordinas A, Sixma J, de Groot PG. Antithrombotic action of annexin V proved as efficient as direct inhibition of tissue factor or thrombin. Eur J Clin Invest. (2006) 36:633-9. doi: 10.1111/j.1365-2362.2006.01698.x

141. Römisch J, Seiffge D, Reiner G, Pâques EP, Heimburger N. In-vivo antithrombotic potency of placenta protein 4 (annexin V) Thromb Res. (1991) 61:93-104. doi: 10.1016/0049-3848(91)90236-P

142. Van Ryn-McKenna J, Merk H, Müller HT, Buchanan MR, Eisert WG. The effects of heparin and annexin $\mathrm{V}$ on fibrin accretion after injury in the jugular veins of rabbits. Thromb Haemost. (1993) 69:227-30. doi: $10.1055 / \mathrm{s}-0038-1651585$

143. Thiagarajan P, Benedict CR. Inhibition of arterial thrombosis by recombinant annexin V in a rabbit carotid artery injury model. Circulation. (1997) 96:2339-47. doi: 10.1161/01.CIR.96.7.2339
144. Kuijpers MJ, Munnix IC, Cosemans JM, Vlijmen BV, Reutelingsperger $\mathrm{CP}$, Egbrink $\mathrm{MO}$, et al. Key role of platelet procoagulant activity in tissue factor-and collagen-dependent thrombus formation in arterioles and venules in vivo differential sensitivity to thrombin inhibition. Microcirculation. (2008) 15:269-82. doi: 10.1080/10739680701 653517

145. Shi J, Pipe SW, Rasmussen JT, Heegaard CW, Gilbert GE. Lactadherin blocks thrombosis and hemostasis in vivo: correlation with platelet phosphatidylserine exposure. J Thromb Haemost. (2008) 6:1167-74. doi: 10.1111/j.1538-7836.2008.03010.x

146. Millington-Burgess SL, Rahman T, Harper MT. An empirical screen of the effects of polyphenolic compounds on platelet scramblase activity. Res Prac Thromb Haemost. (2019) 3(Suppl.1):571

147. Millington-Burgess SL, Rahman T, Harper MT. R5421 is not a selective inhibitor of platelet phosphatidylserine exposure. Res Prac Thromb Haemost. (2019) 3(Suppl.1):148-9.

148. Agbani EO, Williams CM, Li Y, van den Bosch MT, Moore SF, Mauroux A, et al. Aquaporin-1 regulates platelet procoagulant membrane dynamics and in vivo thrombosis. JCI Insight. (2018) 3:99062. doi: 10.1172/jci.insight. 99062

Conflict of Interest: The authors declare that the research was conducted in the absence of any commercial or financial relationships that could be construed as a potential conflict of interest.

Copyright (C) 2020 Reddy and Rand. This is an open-access article distributed under the terms of the Creative Commons Attribution License (CC BY). The use, distribution or reproduction in other forums is permitted, provided the original author(s) and the copyright owner(s) are credited and that the original publication in this journal is cited, in accordance with accepted academic practice. No use, distribution or reproduction is permitted which does not comply with these terms. 